\title{
The Relationship between Organizational Silence and Burnout among Academicians: A Research on Universities in Turkey
}

\author{
Uğur Akın ${ }^{1} \&$ Tarık Ulusoy ${ }^{1}$ \\ ${ }^{1}$ Department of Education, Gaziosmanpaşa University, Tokat, Turkey \\ Correspondence: Tark Ulusoy, Department of Education, Gaziosmanpaşa University, Tokat. E-mail: \\ ulusoytarik1@gmail.com \\ Received: February 9, 2016 \\ Accepted: February 18, 2016 \\ Online Published: February 22, 2016 \\ doi:10.5430/ijhe.v5n2p46 \\ URL: http://dx.doi.org/10.5430/ijhe.v5n2p46
}

This paper was orally presented in 1. International Higher Education Studies Conference (IHEC) 2015.

\begin{abstract}
The aim of this research is to analyze the relationship between organizational silence and burnout levels of academicians. The study group consisted of 190 academicians, who work in 17 state universities that are located in 15 different provinces of Turkey. Data were collected through Causes of Faculty Members' Silence Scale and Maslach Burnout Inventory. The results of the study indicate that silence levels of academicians are medium and burnout levels are low. A positive correlation was identified between organizational silence and burnout levels. Multiple linear regression analysis demonstrates that silence scores were predicting emotional exhaustion, depersonalization and personal accomplishment. In order to reduce burnout to a minimum level in academy, university managers are offered to establish a culture, where academicians are allowed to express their opinions freely. In addition, the study provides suggestions for future research.
\end{abstract}

Keywords: Organizational silence, Burnout, Academicians

\section{Introduction}

The most distinctive feature of human beings that separate them from other living things is perhaps their ability to think and to express their ideas to influence their environments. Organizations, which are established to unite individual efforts for common purposes, also try to reach the best results through gathering different ideas concerning the work together. As Durak (2014) mentions, one of the most important assets of organizations is the innovative, original, critical and different ideas and thoughts of their employees. Particularly at universities, academicians' studies that are based on their creative ideas and thoughts are the most significant products. As it is indicated on the Basic Law of National Education (art. 35) and the Law of Higher Education (art. 4c and art. 12), universities are expected not only to perform education and teaching, but also to be guiding institutions for cultural, economic and social development in order to raise the society's development level. For the accomplishment of these functions of universities, academicians should be able to express their opinions freely, concerning both functioning of universities and scholarly issues. However, findings of current studies demonstrate that academicians in Turkey are hesitant to share their ideas, opinions and suggestions (Bayram, 2010; Çakıcı, 2007; Çakınberk, Dede, \& Yılmaz, 2014; Demir \& Demir, 2012; Özgan \& Külekçi, 2012; Tülübaş \& Celep, 2014; Yaman \& Ruçlar, 2014). In the literature, this situation is conceptualised as organizational silence.

Academicians' inability to express their ideas and preference to remain silent is an undesired organizational behaviour. This undesired situation is expected to cause some negative consequences. The studies conducted both on different organizations (Tahmasebi, Sobhanipour \& Aghaziarati, 2013) and universities (Özgan \& Külekçi, 2012; Kahya, 2015) demonstrate that one of these negative consequences is burnout. This study looks for the relationship between organizational silence and burnout through a more inclusive study group from different universities of different regions in Turkey. In doing so, the study aims to obtain more generalizable results about the relationships between organizational silence and burnout among academicians in Turkey. 


\subsection{Organizational Silence among Academicians}

The concept of silence is attributed negative meanings included introversion, introvert behaviors in psychology and inaction and intimidation of society in sociology; whereas in ethics and philosophy, it is associated with positive meanings such as keeping secrets and mediation (Afşar, 2013). In the literature, it is observed that the concepts of employee silence and organizational silence are used interchangeably for employee's silence (Park \& Keil, 2009). This study considers both concepts in the same meaning as organizational silence. Morrison and Milliken (2000) define organizational silence as conscious choice of employees about not expressing their knowledge and ideas concerning organizational problems (p. 707). According to another definition, organizational silence is the denial of an individual's behavioral, mental and emotional genuine expressions from others, who are capable of altering or fixing the situation (Pinder \& Harlos, 2001, p, 334). According to Bagheri, Zarei and Aeen (2012), organizational silence is the situation in which employees willingly or unwillingly keep information that might be useful for the organization.

It can be said that employees adopt silence after a process. There might be different motivations that push them to be silent (Milliken \& Morrison, 2003; Pinder \& Harlos, 2001; Van Dyne, Ang \& Botero, 2003). On the basis of these motivations, the reasons for organizational silence can be dealt with in several different dimensions. Çakıc1 (2007) analyzes the reasons for organizational silences with five dimensions: administrative reasons, the fear of isolation, operational reasons, lack of experience, and fear of ruining relationships. Van Dyne et al. (2003) define three dimensions: acknowledged silence, defense-oriented silence and silences for the good of the organization. Alparslan (2010) defines organizational silence as a four-dimensional structure consisting of self-defense and fear-oriented silence, indifference and submission oriented silence, pro-social tendency oriented silence and silence for protection of relationship. Kahveci and Demirtaş (2013) analyze organizational silence under five dimensions: school environment, emotions, source of silence, managers and isolation. This study draws from Tülübaş's (2011) study, which is largely based on Brinsfield's (2009) research consisting meticulously conducted dimensions in order to reveal organizational silence of academicians. These dimensions are (1) acquiescence, (2) self-defense, (3) protecting relationships with co-workers and (4) supervisors, (5) organizational regulations, and (6) lack of self-confidence. Those are briefly explained as follows:

\subsubsection{Acquiescence}

The concept is associated with the fact that workers remain to be passive, as they believe that expression of their knowledge, ideas and thought is useless (Ülker \& Kanten, 2009). Employees, even they cannot remain silent, know that talking is meaningless; therefore they strike such an attitude (Milliken, Morrison \& Hewlin, 2003, p. 1468). Tülübas (2011) describes this situation as passive recognition of the status quo. The dominance of bureaucratic mentality at universities might cause critical thinkers to bite back and prevent from expressing their opinions; in other words they retreat into organizational silence.

\subsubsection{Self-defense}

Fear is an important factor, which defines the way of employee's behavior. During expression of opinions, employees might fear from facing negative outcomes; so they might be pushed to silence. For academicians, it is important to be promoted as a result of their scholarly work. Promotion for the case of academy and administration requires a long process and great efforts. For this reasons, academicians might not be critical about status quo in order to protect their careers. They may consciously prefer not to express their views and ideas. Employees might also remain silent due to the fear of exclusion, inability to be promoted and neglect of looking like a problem-causing person. Employees try to avoid from consequences that might occur when they speak out (Pinder \& Harlos, 2001). Employees instinctively try to protect themselves from problematic situations. Previous research showed that employees believe that they may lose their jobs, they cannot achieve promotion, they can face restrictions, they may be held responsible for the situation and they can miss out organizational rewards in case they do not remain silent (Brinsfield et al., 2009; Milliken et al., 2003, p. 1462).

\subsubsection{Protecting Relationships with Co-Workers}

Employees might fall into silence not to be the troubled person within the organization, not to be embarrassed against their friends and due to the possibility that their opinions are not supported by others (Durak, 2014). Bowen and Blackmon (2003) also state that employees, who consider that their opinions are not backed by others, choose to remain silent. The reason for expression of opinions at universities is to acquire superiority in sharing of several resources and to influence the way of work upon one's request. Thoughts concerning the share of resources and the way of doing work can occasionally cause conflicts. Academicians might prefer to be silent to avoid such a conflict 
with their co-workers.

\subsubsection{Protecting Relationships with Supervisors}

Preservation of valuable relations can be a significant reason for silence (Morrison \& Milliken, 2003, p. 1355). When employees talk about a negative situation about the work, they might fear from deterioration of their relations with supervisors, they may believe that they can confront restrictions, they cannot be promoted and even they may lose their jobs; these fears lead to silence (Morrison, Milliken \& Hewlin, 2003, p. 1462). Employees do not desire to be perceived as problematic individuals (Tülübaş, 2011). Studies indicate that transparency and publicity of top-level administration and perceived organizational support lead to a decrease of silence (Erenler, 2010). Two main views might exist for preservation of relationships with supervisors. First, employee can remain silent not to break their relationships with supervisors to protect themselves. This situation can be evaluated under the sub-dimension of self-defense. The other view consists of ideas to gain support of supervisors by remaining silent and maintaining relations with supervisors. Academic promotions depend on reports of academicians' superiors. Therefore, academicians can prefer to be silent in order to get their superiors' support.

\subsubsection{Organizational Regulations}

In classical organizational structures, communication channels from down to top can be limited and insufficient (Ehtiyar \& Yanardağ, 2008, p. 56). In such a situation, as employees believe that they are unable to change this structure within the organization, they may choose to remain silent. In central organizations, whose structures represent bureaucratic hierarchy more, support for organizational silence is more probable (Durak, 2014). There is a common belief that Turkish bureaucracy has a solid and centralist structure. In Turkish society, obedience to the authority is a significant phenomenon in determination of individual behaviors. When this general structure and limited and insufficient channels of communication within the organization are combined, it is expected that employees experience organizational silence that is based on institutional regulations (Aytaç, 2007, p. 149). Although universities in Turkey represent a loose bureaucratic structure in comparison to other public institutions, it cannot be claimed that they are totally free from communicative limitations due to bureaucratic structure. For this reason, one of the basic reasons for academicians to remain silent can be institutional regulations.

\subsubsection{Lack of Self-Confidence}

An individual's ability to express himself without scaring or hesitating depends on the level of his/her self-confidence. Individuals with low self-confidence tend to protect themselves more. Speaking frankly may sometimes award an individual a status; however in case of failure, there could be risks for negative outcomes. Individuals with low self-confidence avoid expressing themselves and presenting their opinions due to the belief of these risks (Premeaux \& Bedeian, 2003, p. 1543). Kutlay's (2012) study also demonstrates that there are significant correlations between self-efficacy perceptions of research assistants and their behaviors of silence. Accordingly, research assistants with negative perceptions towards their self-efficacy remain more silent.

\subsection{Burnout among Teaching Staff}

The concept of burnout was first used by Freudenberger (1974) to explain fatigue status of voluntary employees of health institutions in United States of America, which occurred because of their physical and mental exhaustion and to discuss negative reflections of this situation on employees and working environment. Schwarzer, Schmitz and Tang (2000) define burnout as a chronic status of exhaustion stemming from long-term interpersonal stress among professions of service sector. According to Maslach and Jackson (1981) burnout is a syndrome usually occurring among employees in the service sector, who work through face-to-face communication with other people. Work relations, which are often based on resolution of the customer's psychological, social or physical problems, cause chronic stress-oriented burnout. Employees, who experience burnout, have low morale. They do not go to work regularly or even change occupation. High level of stress, physical exhaustion, sleeping disorders, increase of alcohol and drug use, marriage and family problems are among negative consequences of burnout.

Vanguard studies to determine factors causing burnout and to measure it were conducted by Maslach and his colleagues (Maslach, 1993; Maslach \& Jackson, 1981). These studies define burnout as a three-dimensional structure. These are emotional exhaustion, depersonalization and personal accomplishment. According to Schwarzer et al. (2000), as a reflection of intensive stress, emotional exhaustion refers to depletion of all emotional sources of an individual. Among Individuals that are emotionally exhausted, fatigue, intolerance and loss of energy can be observed. Employees that experience depersonalization have symptoms such as negativity, irritability, loss of idealism and negative or inappropriate behaviors. These employees might behave negatively, unemotionally or extremely carelessly to customers. Personal accomplishment refers to an employee's self-evaluation. This 
self-evaluation, consequently occur after emotional exhaustion and depersonalization, is negatively concluded. The employee thinks that his/her professional efficiency is decreased, his/her productivity and capacity are reduced and $\mathrm{s} /$ he is unable to cope with necessities of the work.

Academicians constitute a working group that they have intensive relations with their superiors, co-workers, administrative personnel, several segments of society, and students. In these relations, the effort to meet expectations of these parties might cause academicians' to experience burnout. Results of studies indicate that burnout levels of academicians are considerable (Brewer \& McMahan, 2003; Hogan \& McKnight, 2007; Rothmann \& Barkhuizen, 2008). According to Watts and Robertson (2011), academicians that meet many students through a face-to-face communication, experience burnout to some degree, similar to the health sector employees and teachers. According to Lackritz (2004), in America, 20\% of academicians suffer from high level of burnout. The same study finds out that lack of job security, excessive course work and workload in general increase burnout. The negativities in working environment mentioned in this study is likely valid for universities in Turkey as well. The research in Turkey also indicates that academicians experience several levels of burnout (Ardıç \& Polatçı, 2008; Çavuşoğlu, Ünver, Doğan, İslamoğlu \& Özdemir, 2015; Konakay, 2013; Kutanis \& Karakiraz, 2013; Sağlam, 2011; Toker, 2011).

\subsection{The Relationship between Organizational Silence and Burnout}

Academician's preference to remain silent due to several reasons is an undesired situation for both academicians and universities. This undesired situation is accompanied with some negative consequences among employees. Cynism levels of silent employees increase (Nartgün \& Kartal, 2013) whereas their life satisfaction levels decrease (Șimșek \& Aktaş, 2014). These employees have lower organizational commitment (Köse, 2014; Ülker \& Kanten, 2009) and organizational citizenship (Çınar, Karcıoğlu \& Alioğulları, 2013; Korkmaz \& Aydemir, 2015). They perceive less justice in their organizations (İşleyici, 2015). Kahya (2015) states that employees, who are not allowed to talk about their tasks and repressed about this issue, are not expected to work actively and efficiently; after a time they might experience physical, mental and emotional burnout due to excessive stress. Zamini, Zamini and Barzegary (2011) report that a university culture lacking participation leads to increase of burnout.

The qualitative results of Özgan and Külekçi (2012) on 14 academicians indicate that silence psychologically exhaust academicians. Kahya's (2015) study on Ataturk University academicians shows that organizational silence causes burnout. But these two studies cited above are very local and may not give the answer for what was the case for Turkey. So, there is need in the literature for further studies covering the relationships between organizational silence and burnout levels of academicians from different universities extensively, in the case of Turkey.

\subsection{The Aim of the Research}

The aim of this research is to analyze the relationships between organizational silence and burnout levels of academicians in Turkey. With this purpose, the study attempts to answer the following questions:

1. What are the levels of organizational silence and burnout of academicians?

2. Is there a significant relationship between organizational silence and burnout levels of academicians?

3. Does organizational silence predict burnout among academicians?

\section{Method}

This research employed quantitative research method. Predictive relational survey model is employed that attempt to predict a variable based on another (Büyüköztürk, Çakmak, Akgün, Karadeniz \& Demirel, 2012, p. 226). This research, which tests the prediction of academicians' silence of their burnout, is designed as a predictive relational survey model.

\subsection{Participant Characteristics}

The study group consists of 190 academicians in 17 different state universities (two universities from Istanbul and Ankara) in 15 different provinces of Turkey. Participants are between 24 and $64(\bar{X}=38.24)$; they were selected randomly in accordance with the simple random sampling technique (Balc1, 2011, p. 96). Characteristics of academicians in the study group are presented on Table 1. 
Table 1. Characteristics of Study Group

\begin{tabular}{llcc}
\hline Variable & & $f$ & $\%$ \\
\hline \multirow{2}{*}{ Gender } & Female & 101 & 53.2 \\
& Male & 89 & 46.8 \\
\hline \multirow{2}{*}{ Title } & Research Assistant & 65 & 34.2 \\
& Instructor & 18 & 9.5 \\
& Assistant Professor & 37 & 19.5 \\
& Associate Professor & 41 & 21.6 \\
& Professor & 29 & 15.3 \\
\hline \multirow{3}{*}{ Faculty } & Education & 93 & 48.9 \\
& Arts and Sciences & 46 & 24.2 \\
& Economics and Adm. Sci. & 51 & 26.8 \\
\hline Total & & 190 & 100
\end{tabular}

As seen on Table 1, there were 101 female, 89 male participants. 65 of them were research assistants, 18 were instructors, 37 were assistant professors, 41 were associate professors, and 29 were professors. 93 of the participants work at faculty of education, 46 of them were from arts and sciences, and 51 of them work at faculty of economics and administrative sciences.

\subsection{Measures}

In order to collect data, two instruments were used in addition to personal information form. These are: "Causes of Faculty Members' Silence Scale" and "Maslach Burnout Inventory".

\subsubsection{The Causes of Faculty Members' Silence Scale}

This study draws from Tülübaş's (2011) "Causes of Faculty Members' Silence Scale”, which is largely based on Brinsfield's (2009) scale. The study's preference of this scale is two-fold. First, it is considered that the scale was developed after comprehensive research on academicians. Second, its validity and reliability was tested by Tülübaş (2011) on academicians. The scale consists of 31 items and it measures silence through six dimensions that are associated with silence. These sub dimensions are acquiescence (10 items), self-defense (6 items), protecting relationships with co-workers (4 items), protecting relationships with supervisors (4 items), organizational regulations ( 3 items), and lack of self-confidence (4 items). High scores obtained from the scale represent high levels of silence. Tülübaş (2011) reported Cronbach's Alpha values as $.93, .86, .89, .91, .81$ and .70 respectively for six dimensions. For this study, Cronbach's Alpha scores were found as $.93, .90, .84, .93, .67$ and .79 respectively.

\subsubsection{Maslach Burnout Inventory}

Another scale that was employed in order to collect data was Maslach Burnout Inventory, which was developed by Maslach and Jackson (1981). It was adapted to Turkish by Ergin (1992). The scale consists of 22 items and it measures burnout through three different dimensions. The first dimension is emotional exhaustion, consisting of 9 items. The second one is depersonalization, consisting of 5 questions and the last one is personal accomplishment with 8 questions. The personal accomplishment expressions on the scale, in contrast to other scales, are positive. High scores obtained these refer to high personal accomplishment; on the other hand they refer low levels of burnout. In this sense, analyzes were made through reversal of scores from the personal accomplishment sub-dimension. Accordingly, high scores from sub dimensions of emotional exhaustion and depersonalization and low scores from depersonalization refer to high levels of burnout. The Cronbach's Alpha scores were .91, .74, and .70 respectively for this study.

\subsection{Data Collection and Analyzes}

Data were collected through internet by using online questionnaires. Online questionnaire, which consists of personal information tool, silence and burnout scales, was delivered to participants via e-mail. Participants e-mail addresses were gathered from university websites. In doing so, 3000 academicians were contacted and 194 of them responded. 4 of 194 forms were removed due to several causes and analyzes were made with 190 of them. In description of the sample, frequency and percentage, in reliability analyzes of scales Cronbach's Alpha reliability coefficient, in 
description of academicians' silence and burnout levels, mean and standard deviation were employed. Each question of both scales' score range between 1 and 5 . The scores were assessed in the following way: $1.00-1.79=$ strongly disagree, $1.80-2.59=$ slightly agree, $2.60-3.39=$ somewhat agree, $3.40-4.19=$ strongly agree and $4.20-5.00=$ totally agree. Pearson correlation coefficient and multiple linear regression analyzes were also employed in order to test the relationships between organizational silence and burnout of academicians.

\section{Results}

The first question sought to find out academicians' organizational silence and burnout levels. In order to reply this questions, means and standard deviation values were calculated through participants' answers concerning organizational silence and burnout scales. The results are presented on Table 2.

Table 2. Organizational Silence and Burnout Levels

\begin{tabular}{llll}
\hline Variables & Dimensions & $\bar{X}$ & sd \\
\hline \multirow{4}{*}{ Organizational Silence } & Acquiescence & 3.55 & .97 \\
& Self-defense & 2.77 & 1.11 \\
& Relationships with Co-Workers & 3.40 & 1.51 \\
& Relationships with Supervisors & 3.21 & 1.20 \\
& Organizational Regulations & 3.96 & .86 \\
& Lack of Self-Confidence & 2.39 & .95 \\
& Total Organizational Silence & 3.22 & .71 \\
\hline \multirow{3}{*}{ Burnout } & Emotional exhaustion & 2.52 & .97 \\
& Depersonalization & 2.15 & .79 \\
& Personal Accomplishment & 2.28 & .58 \\
& Total Burnout & 2.34 & .64
\end{tabular}

As seen on Table 2, academicians experience medium level of silence $(\bar{X}=3.22)$. In addition, participants mostly remain silent due to institutional regulations $(\bar{X}=3.96)$. Silence because of lack of self-confidence was found at a minimum level $(\bar{X}=2.39)$. Academicians stated that they slightly agree with expressions with regard to burnout $(\bar{X}$ $=2.34)$. Participants experienced burnout mostly on emotional exhaustion dimension $(\bar{X}=2.52)$; whereas they expressed that they experienced burnout lastly on depersonalization dimension $(\bar{X}=2.15)$.

Another question in this research is whether there is a significant relationship between academicians' organizational silence and burnout levels. In order to find an answer to this question, Pearson correlation coefficients were calculated and results are presented on Table 3.

Table 3. Relationship between Organizational Silence and Burnout

\begin{tabular}{|c|c|c|c|c|c|c|c|c|c|c|c|}
\hline Variables & 1 & 2 & 3 & 4 & 5 & 6 & 7 & 8 & 9 & 10 & 11 \\
\hline 1. Acquiescence & 1 & $.34^{* *}$ & .02 & -.07 & $.61^{* *}$ & $.15^{* *}$ & $.63^{* *}$ & $.47^{* *}$ & $.39^{* *}$ & .01 & $.41^{* *}$ \\
\hline 2. Self-defense & & 1 & $.55^{* *}$ & $.55^{* *}$ & $.41^{* *}$ & $.66^{* *}$ & $.85^{* *}$ & $.33^{* *}$ & $.30^{* *}$ & .12 & $.34^{* *}$ \\
\hline 3. Relationships with Co-Workers & & & 1 & $.80^{* *}$ & $.18^{* *}$ & $.51^{* *}$ & $.67^{* *}$ & -.01 & .04 & .02 & .01 \\
\hline 4. Relationships with Supervisors & & & & 1 & .09 & $.54^{* *}$ & $.62^{* *}$ & .03 & .07 & .01 & .05 \\
\hline 5. Organizational Regulations & & & & & 1 & $.26^{* *}$ & $.61^{* *}$ & $.45^{* *}$ & $.28^{* *}$ & .03 & $.37^{* *}$ \\
\hline 6. Lack of Self-Confidence & & & & & & 1 & $.69^{* *}$ & $.24^{* *}$ & $.39^{* *}$ & $.25^{* *}$ & $.35^{* *}$ \\
\hline 7. Total Organizational Silence & & & & & & & 1 & $.41^{* *}$ & $.39^{* *}$ & .09 & $.40^{* *}$ \\
\hline 8. Emotional exhaustion & & & & & & & & 1 & $.68^{* *}$ & $.33^{* *}$ & $.91^{* *}$ \\
\hline 9. Depersonalization & & & & & & & & & 1 & $.33^{* *}$ & $.81^{* *}$ \\
\hline 10. Personal Accomplishment & & & & & & & & & & 1 & $.63^{* *}$ \\
\hline 11. Total Burnout & & & & & & & & & & & 1 \\
\hline
\end{tabular}

$* * \mathrm{p}<.01$ 
As Table 3 indicates, there is a positive, medium-level significant relationship between academicians' organizational silence and burnout levels $(r=.40, p<.01)$. Evaluation on the basis of dimensions demonstrated that academicians' experiences of organizational silence present a positive and significant relationship between emotional exhaustion, depersonalization and total burnout levels in all dimensions, with the exception of relationships with co-workers and supervisors. Burnout experienced on the dimension of personal accomplishment was only significantly related to silence due to lack of self-confidence.

The last question of this research was whether organizational silence levels of academicians predict their burnout levels. In order to find an answer to this question, a multiple regression analysis was conducted. Results of the prediction of academicians' emotional exhaustion levels by their perception of organizational silence are shown on Table 4.

Table 4. Prediction of Emotional Exhaustion

\begin{tabular}{llllll}
\hline Variables & $B$ & Standard Error & $\beta$ & $t$ & $p$ \\
\hline Constant & .37 & .33 & & 1.15 & .25 \\
Acquiescence & .27 & .08 & .28 & 3.43 & $.00^{*}$ \\
Self-defense & .14 & .08 & .17 & 1.75 & .08 \\
Relationships with Co-Workers & -.28 & .09 & -.33 & -3.20 & $.00^{*}$ \\
Relationships with Supervisors & .11 & .09 & .14 & 1.30 & .19 \\
Organizational Regulations & .25 & .09 & .23 & 2.86 & $.00^{*}$ \\
Lack of Self-Confidence & .13 & .09 & .13 & 1.55 & .12 \\
\hline
\end{tabular}

$R=.58, R^{2}=.33$, Adj. $R^{2}=.31, F=15.28, \stackrel{*}{p} p<.01$

According to Table 5, the model, which tested prediction of emotional exhaustion by organizational silence was found significant $(F=15.28, p<.01)$. Organizational silence explained $33 \%$ of emotional exhaustion $\left(R^{2}=.33\right)$. While t values were examined, it was observed that the dimensions of acquiescence, relationships with co-workers, and organizational regulations were significant predictors of emotional exhaustion $(p<.01)$. Considering $\beta$ coefficients, the most significant predictor of emotional exhaustion was silence due to protect relationships with co-workers $(\beta=$ $-.33)$.

Multiple regression analysis results concerning the status of the prediction of academicians' burnout levels by their perception of organizational silence on the dimension of depersonalization are shown on Table 5.

Table 5. Prediction of Depersonalization

\begin{tabular}{llllll}
\hline Variables & $B$ & Standard Error & $\beta$ & $t$ & $p$ \\
\hline Constant & .73 & .28 & & 2.65 & .01 \\
Acquiescence & .26 & .07 & .32 & 3.87 & $.00^{*}$ \\
Self-defense & .00 & .07 & .00 & .01 & .99 \\
Relationships with Co-Workers & -.14 & .07 & -.21 & -1.91 & .06 \\
Relationships with Supervisors & .02 & .07 & .03 & .22 & .82 \\
Organizational Regulations & .01 & .08 & .01 & .16 & .87 \\
Lack of Self-Confidence & .36 & .07 & .43 & 5.00 & $.00^{*}$ \\
\hline
\end{tabular}

$R=.54, R^{2}=.29$, Adj. $R^{2}=.27, F=12.59, p<.01$

As seen on Table 5, the model, which tested the prediction of depersonalization by organizational silence was found significant $(F=12.59, p<.01)$. Organizational silence totally explained $29 \%$ of burnout on the dimension of depersonalization $\left(R^{2}=.29\right)$. According to t values, it was observed that acquiescence and lack of self-confidence were significant predictors of depersonalization $(p<.01)$. Considering $\beta$ coefficients, the most significant predictor of depersonalization dimension was silence stemming from lack of self-confidence $(\beta=.43)$.

Multiple regression analysis results concerning the prediction of academicians' personal accomplishment levels by their perception of organizational silence are presented on Table 6. 
Table 6. Prediction of Personal Accomplishment

\begin{tabular}{llllll}
\hline Variables & $B$ & Standard Error & $\beta$ & $t$ & $p$ \\
\hline Constant & 2.21 & .23 & & 9.58 & .00 \\
Acquiescence & -.02 & .06 & -.04 & -.43 & .67 \\
Self-defense & .02 & .06 & .04 & .40 & .69 \\
Relationships with Co-Workers & -.03 & .06 & -.05 & -.43 & .67 \\
Relationships with Supervisors & -.07 & .06 & -.15 & -1.21 & .23 \\
Organizational Regulations & -.02 & .06 & -.03 & -.34 & .73 \\
Lack of Self-Confidence & .21 & .06 & .34 & 3.48 & $.00^{*}$ \\
\hline
\end{tabular}

$R=.29, R^{2}=.09$, Adj. $R^{2}=.06, F=2.87, p<.01$

As Table 6 indicates, the model testing the prediction of burnout by organizational silence on the dimension of personal accomplishment was found significant $(F=2.86, p<.01)$. Sub dimensions of organizational silence explained $9 \%$ of personal accomplishment $\left(R^{2}=\right.$. 09). While $\mathrm{t}$ values were examined, it was observed that only the lack of self-confidence was significant predictor of personal accomplishment $(p<.01)$.

\section{Discussion}

Results of this research show that academicians experience medium-level of silence. Academicians mostly remain silent because of institutional regulations. In other words, academicians stated that they preferred to be silent due to lack of communication channels and environments at universities, where they can freely share their opinions. The least significant factor for academicians to remain silent is lack of self-confidence. Similarly, Tülübaş and Celep (2014) reported that institutional regulations play a considerable role whereas lack of self-confidence is relatively an insignificant factor. Bisel and Arterburn (2012) found that the most important reason for employees to be silent is to prevent possible damages in the future. Morrison and Milliken (2000) stated that organizational silence is closely associated with the organization's structure and its policies. According to them, administrators avoid receiving negative feedback; therefore this avoidance hinders them to support an environment, in which employees can freely express themselves. Results of Milliken et al. (2003) seem to support this hypothesis that they found out the most significant reasons for employees' silence are organizational features such as hierarchical structure and non-supportive organizational culture. Yaman and Ruçlar (2014) also reveal that organizational culture is among significant predictors of academicians' silence. Although it is expected that universities are more flexible bureaucratic organizations, in practice administrators are dominant for the organization's administrative structure. Hofstede's $(1984 ; 2001)$ studies, which present differentiation of organizational structures in different cultures, indicate that organizational hierarchy in Turkey is stronger and the distance between administrators and employees is larger. A similar situation might occur at universities in Turkey. This large distance between academicians and administrators may push academicians into silence. Çaloğlu's (2014) research supports this assumption that it identified that vertical communitarian culture in Hofstede's classification is associated with organizational silence. In the light of this discussion, it is suggested that administrators should provide an environment at universities, in which academicians can express their views without hesitation. From department and faculty administration to university administration, platforms should be established on each subject. Academicians should be encouraged to participate in these platforms and to express their opinions. Therefore, it is considered that academicians can be freed from institutional regulations, which seem to be the most important barrier against their freedom of expression.

The results reveal that academicians have low levels of burnout. Nevertheless, academicians experience emotional exhaustion in a relatively high level. Studies on Turkey reported generally low or medium burnout levels for academicians (Ardıç \& Polatçı; Çavuşoğlu et al., 2015; Sağlam, 2011). Watts and Robertson's (2011) meta-analysis, covering seven different countries, show that one of the most important sources of academicians' burnout is the face-to-face communication with students. Academicians in Turkey generally complain about excessive course work. This means interaction with many students. Despite this situation, it is interesting to find out that burnout levels are relatively low. This can also be explained through culture again. In Turkey, manager-employee relations are authoritarian by nature; it can be claimed that this type of relationship prevails in academicians-students relations. As Maslach and Jackson (1981) mention, the relationship between the service provider and service receiver are generally built on the service receiver's psychological, social or physical problems. These individuals' problems are not easy to be solved. In this process, employees experience burnout due to chronic stress. In terms of academicians-students 
relations, students' relations with academicians are based on authority and consequently on a minimum level.

According to correlation analysis results, an increase in organizational silence levels of academicians results in increase in their burnout levels. When organizational silence decreases, burnout also decreases as well. Milliken and Morrison (2003) stated that employees have to choose between to talk about work or to be silent. Individuals make this choice in a hierarchical organization, in which managers do not wish to hear problems and they mostly prefer to be silent. This choice of employees has several negative consequences. According to Aktaş and Şimşek's (2015) findings, there is a significant relationship between employees' silence and burnout levels. Tahmasebi et al. (2013) also report a positive relationship between organizational silence and emotional exhaustion and depersonalization. According to Morrison and Milliken (2000), stress is one of the most significant consequences of organizational silence. It is known that intensive work stress paves the way for burnout. Both theoretical and empirical studies in the literature and the results of this study demonstrate that organizational silence is associated with academicians' stress and stress-oriented burnout.

Academicians' silence predicts their emotional exhaustion levels. According to the results, academicians, who remain silent in order to protect their relationships with co-workers, experience higher level of emotional exhaustion. Murat's (2003) findings show that the most important factors for academicians' burnout is their relationships with co-workers. In Turkey, supervisors of academicians play a decisive role in their appointment and promotion. Professors' positive opinions and reports are necessary for the titles of associate professorship and professorship. This situation forces academicians, from being research assistant to become a professor, to be more cautious in their relations. It may also result in silence and emotional exhaustion of academicians. Some research findings (Küçüksüleymanoğlu, 2007; Toker, 2011), indicating research assistants experience higher levels of emotional exhaustion than professors, support this assumption.

Organizational silence levels of participants predict their depersonalization. The most important predictor of burnout is silence due to lack of self-confidence. Tümkaya (2000) asserts that academicians constitute a working group with heavy and important responsibilities. Accordingly, academicians who lack the ability to cope with these responsibilities live in anger, despair, disappointment, indifference, and reluctance and they become introverted. In other words academicians, who are unable to handle heavy responsibilities of the academia, become self-enclosed and experience burnout. According to Morrison and Phelps (1999), individuals' perception of self-efficacy positively affects them in taking responsibilities. Then, academicians with lower perception of self-efficacy and lower self-confidence might avoid responsibilities, choose to be introverted and remain silent. Such introversion might cause academicians to experience burnout.

Finally, organizational silence also predicts personal accomplishment. On this dimension, the most important predictor of burnout is again silence due to lack of self-confidence. In this research, items used to measure silence based on lack of self-confidence (Tülübaş, 2011) and personal accomplishment (Maslach \& Jackson, 1981) include negative perceptions concerning academicians' own work performance. Therefore it is expected academicians, who remain silent because of lack of self-confidence, experience burnout on the personal accomplishment dimension. Şehitoğlu's (2010) results show that organizational silence affect employee performance negatively. Aktaş and Şimşek (2014) report that acknowledged silence behavior is negatively related with individual performance for employees. Researchers mention that acknowledged silence behavior, as a negative personality trait, is more common among introverted individuals. Similarly, lack of self-confidence is also a negative personality trait. For this reasons, silence might affect perception of personal accomplishment negatively through reducing individual performance.

\section{Conculusion}

In conclusion, academicians avoid expressing their opinions on work-related subjects due to several reasons at universities in Turkey. Organizational silence considerably explains academicians' burnout. These results are enlightening for understanding the nature of burn out among academicians. University administrators, in order to prevent academicians from experiencing burnout, should establish an organizational culture for them to express their ideas and opinions freely. Such an organizational culture requires senior administrators to be particularly tolerant towards academicians' views and suggestions. In an open and communicative environment model, which is initiated by senior administrators of universities, academicians are expected to experience lower levels of burnout. One important limitation of this research is that it is designed through quantitative method and does not included specific patterns causing organizational silence and in-depth samples. Considering these limitations, researchers are suggested to do qualitative research, which would profoundly analyze the relationships between academicians' behavior of silence and their burnout. 


\section{References}

Afşar, L. (2013). Örgütsel sessizlik ve örgütsel güven ilişkisi: Konuya ilişskin bir araştırma [Correlation of organizational silence and organizational trust: A research on the subject]. Unpublished master's thesis, İstanbul University Graduate School of Social Sciences, İstanbul.

Aktaş, H. \& Şimşek, E. (2014). The interactions of organizational silence with perceived individual performance, organizational culture, and demographic variables. Akdeniz Üniversitesi İktisadi ve İdari Bilimler Fakültesi Dergisi, 28, 24-52.

Aktaş, H. \& Şimşek, E. (2015). The role of perceptions of job satisfaction and emotional burnout in individuals' organizational silence attitudes. International Journal of Management Economics and Business, 11(24), 205-230. http://dx.doi.org/10.17130/ijmeb.2015.11.24.529

Alparslan, A.M. (2010). Örgütsel sessizlik iklimi ve işgören sessizlik davranışları arasındaki etkileşim: Mehmet Akif Ersoy Üniversitesi ögretim elemanları üzerinde bir araştırma [The interaction between organizational silence climate and employee silence behavior: A survey on instructors of Mehmet Akif Ersoy üniversitesi]. Unpublished master's thesis. Süleyman Demirel University Graduate School of Social Sciences, Isparta.

Ardıç, K., \& Polatcı, S. (2008). Emotional exhaustion: An application to academic personal (The case of Gaziosmanpaşa University). İktisadi ve İdari Bilimler Fakültesi Dergisi, 10(2), 1-28.

Aytaç, Ö. (2007). Türk bürokrasi kültürü: Yönetsel ve toplumsal bir perspektif [Turkish bureaucratic culture: An administrative and social perspective]. In E. Ramazan \& Ö. Aytaç (Eds.), Kültürel Bağlamda Yönetsel ve Toplumsal Bir Perspektif [An administrative and social perspective in cultural context] (pp. 135-182), İstanbul: Turkish Psychologists Association Publications.

Balc1, A. (2011). Sosyal bilimlerde araştirma: Yöntem, teknik ve ilkeler [Research in social sciences: Methods, techniques, and principles]. Ankara: Pegem Akademi.

Bagheri, G., Zarei, R., \& Aeen, M. N. (2012). Organizational silence: Basic concepts and its development factors. Ideal Type of Management, 1(1), 47-58.

Bayram, T.Y. (2010). Organizational silence in universities. Unpublished master's thesis. Abant İzzet Baysal University. Graduate School of Social Sciences. Bolu, Turkey.

Brewer, E., \& McMahan, J. (2003). Job stress and burnout among industrial and technical teacher educators. Journal of Vocational Education Research, 28(2), 125-140. http://dx.doi.org/10.5328/JVER28.2.125

Bisel, R.S., \& Arterburn, E.N. (2012). Making sense of organizational members' silence: A sensemaking-resource model. Communication Research Reports, 29(3), 217-226. http://dx.doi.org/10.1080/08824096.2012.684985

Brinsfield, C. T. (2009). Employee silence: Investigation of dimensionality, development of measures, and examination of related factors. Unpublished doctoral dissertation, The Ohio State University, USA.

Bowen, F., \& Blackmon, K. (2003). Spirals of silence: The dynamic effects of diversity on organizational voice. Journal of Management Studies, 40(6), 1393-1417. http://dx.doi.org/10.1111/1467-6486.00385

Büyüköztürk, Ş., Çakmak, E. K., Akgün, Ö. A., Karadeniz, Ş., \& Demirel, F. (2012). Bilimsel araştırma yöntemleri [Scientific research methods]. Ankara: Pegem Akademi.

Cakinberk, A.K., Dede, N.P., \& Yilmaz, G. (2014). Relationship between organizational trust and organizational silence: an example of public university. Journal of Economics Finance and Accounting, 1(2), 91-105.

Çakıcı, A. (2007). Örgütlerde sessiz kalınan konular sessizliğin nedenleri ve algılanan sonuçları üzerine bir araştırma [A research on issues, causes and perceptional results of silence at organizations]. Çukurova University Journal of Graduate School of Social Sciences, 17(1), 117-134.

Çavuşoğlu, D.Ö. (2014). An empirical research on organizational silence and cultural variables. Unpublished master's thesis. Ufuk University Graduate School of Social Sciences. Ankara, Turkey.

Çavuşoğlu, G., Ünver, Ş., Doğan, E., İslamoğlu, İ., \& Özdemir, S. (2015). Comparison of the burnout levels of academics in the faculty of sports sciences and other faculties. Spor Yönetimi ve Bilgi Teknolojileri Dergisi [The Journal of Sport Management and Information Sciences], 10(1), 4-13.

Çınar, O., Karcıoğlu, F., \& Alioğulları, Z. D. (2013). The relationship between organizational silence and organizational citizenship behavior: A survey study in the province of Erzurum, Turkey. Procedia-Social and Behavioral Sciences, 99, 314-321. http://dx.doi.org/10.1016/j.sbspro.2013.10.499 
Demir, M, \& Demir, Ş.Ş. (2012). Yükseköğretim kurumlarında örgütsel sessizlik: Turizm lisans eğitimi kurumları örneği [Organizational silence at the institutions of higher education: a study at institutions of tourism bachelor's degree-granting]. Milli Eğitim Dergisi, 193, 184-199.

Durak, İ. (2014). Örgütsel sessizliğin demografik ve kurumsal faktörlerle ilişkisi: Öğretim elemanları üzerine bir araştırma [Relationships between organizational silence and demographics, institutional factors: a study on academic staff]. Atatürk University Journal of Economics and Administrative Sciences, 28(2), 89-108.

Ehtiyar, R., \& Yanardağ, M. (2008). Organizational silence: A survey on employees working in a chain hotel. Tourism and Hospitality Management, 14(1), 51-68.

Erenler, E. (2010). The relationship of employee silence behaviour with some personal and organizational features: a field study on tourism industry. Unpublished doctoral dissertation. Hacettepe University Graduate School of Social Sciences.

Ergin, C. (1992). Doktor ve hemşirelerde tükenmişlik ve Maslach Tükenmişlik Ölçeği'nin uyarlanması [Adaptation of Maslach Burnout Inventory on doctors and nurses]. In R. Bayraktar ve İ. Dağ (Eds.), 7. Ulusal Psikoloji Kongresi Bilimsel Çalışmaları [7. National Psychology Congress Studies] (pp. 143-154). Ankara: Hacettepe University.

Freudenberger, H.J. (1974). Staff burn-out. Journal of Social Issues, 30(1), 159-165. http://dx.doi.org/10.1111/j.1540-4560.1974.tb00706.x

Hofstede, G. (1984). Culture's consequences: International differences in work related values. California: Sage.

Hofstede, G. (2001). Culture's consequences: Comparing values, behaviors, institutions, and organizations across nations. California: Sage.

Hogan, R.L., \& McKnight, M.A. (2007). Exploring burnout among university online instructors: An initial investigation. The Internet and Higher Education, 10(2), 117-124. http://dx.doi.org/10.1016/j.iheduc.2007.03.001

İşleyici, K. (2015). Investigation of the relationship between organizational justice and organizational silence: Zonguldak province sample. Unpublished master's thesis. Abant İzzet Baysal University Graduate School of Educational Sciences. Bolu, Turkey.

Kahveci, G. \& Demirtaş, Z. (2013). Development study of organizational silence scale for teachers. Electronic Journal of Social Sciences, 12(43), 167-182.

Kahya, C. (2015). The relationship between organizational silence and burnout syndrome. Turkish Studies, 10(10), 523-546. http://dx.doi.org/10.7827/TurkishStudies.8335

Konakay, G. (2013). A research about the relationship between emotional intelligence factors and burnout factors of academicians: Case of Kocaeli University. Dokuz Eylül Üniversitesi Sosyal Bilimler Enstitüsü Dergisi [Dokuz Eylül University Journal of Graduate School of Social Sciences], 15(1), 121-144.

Korkmaz, O. \& Aydemir, S. (2015). A research on determining the relationship between organisational silence and organisational citizenship behaviour. Yönetim ve Ekonomi Araştırmalarl Dergisi, 13(2), 140-165. doi: http://dx.doi.org/10.11611/JMER578

Köse, E. K. (2014). Relationships between teachers' organizational commitment and organizational silence in disadvantaged schools. International Journal of Turkish Educational Sciences, 2(2), 28-36.

Kutlay, Y. (2012). The effect of organizational devotion and self-sufficiency of research assistants on organizational silence. Unpublished master's thesis. Süleyman Demirel University Graduate School of Social Sciences. Isparta, Turkey.

Küçüksüleymanoğlu, R. (2007). Eğitim fakültesi öğretim elemanlarının tükenmişlik düzeyleri [Burnout levels of education faculty teaching staff]. Eurasian Journal of Educational Research, 28, 101-112.

Lackritz, J.R. (2004). Exploring burnout among university faculty: Incidence, performance, and demographic issues. Teaching and Teacher Education, 20(7), 713-729. http://dx.doi.org/10.1016/j.tate.2004.07.002

Maslach, C. (1993). Burnout: A multidimensional perspective. In W.B. Schaufeli, C. Maslach, \& T. Marek (eds.). Professional burnout: Recent development in theory and research (pp. 19-32). NY: Taylor \& Francis.

Maslach, C., \& Jackson, S.E. (1981). The measurement of experienced burnout. Journal of Occupational Behavior, 2(2), 99-113. http://dx.doi.org/10.1002/job.4030020205 
Milliken, F.J., \& Morrison, E.W. (2003). Shades of silence: Emerging themes and future directions for research on silence in organizations. Journal of Management Studies, 40(6), 1563-1568. http://dx.doi.org/10.1111/1467-6486.00391

Milliken, F.J., Morrison, E.W., \& Hewlin, P.F. (2003). An exploratory study of employee silence: Issues that employees don't communicate upward and why. Journal of Management Studies, 40(6), 1453-1476. http://dx.doi.org/10.1111/1467-6486.00387

Morrison, E.W., \& Milliken, F.J. (2000). Organizational silence: a barrier to change and development in a pluralistic world. Academy of Management Review, 25(4), 706-725. http://dx.doi.org/10.5465/AMR.2000.3707697

Morrison, E.W., \& Milliken, F.J. (2003). Speaking up, remaining silent: the dynamics of voice and silence in organizations. Journal of Management Studies, 40(6), 1353-1358. http://dx.doi.org/10.1111/1467-6486.00383

Morrison, E.W., \& Phelps, C.C. (1999). Taking charge at work: Extrarole efforts to initiate workplace change. Academy of Management Journal, 42, 403-419. http://dx.doi.org/10.2307/257011

Murat, M. (2003). Burnout among collage teaching staff. Turkish Psychological Counseling and Guidance Journal, 2(19), 25-34.

Nartgün, Ş.S., \& Kartal, V. (2013). Teachers' perceptions on organizational cynicism and organizational silence. Bartin University Journal of Faculty of Education, 2(2), 47-67.

Özgan, H., \& Külekçi, E. (2012). Öğretim elemanlarinin sessizlik nedenleri ve üniversitelerine etkileri [The reasons of academic staff silence and its effect on their university]. e-International Journal of Educational Research, $3(4), 33-49$.

Park, C., \& Keil, M. (2009). Organizational silence and whistle-blowing on IT projects: An integrated model. Decision Sciences, 40(4), 901-918. http://dx.doi.org/10.1111/j.1540-5915.2009.00255.x

Pinder, C. C., \& Harlos, K. P. (2001). Employee silence: quiescence and acquiescence as responses to perceived injustice. Research in Personnel and Human Resources Management, 20, 331-370. http://dx.doi.org/10.1016/s0742-7301(01)20007-3

Premeaux, S.F., \& Bedeian, A.G. (2003). Breaking the silence: The moderating effects of self-monitoring in predicting speaking up in the workplace. Journal of Management Studies, 40(6), 1537-1562. http://dx.doi.org/10.1111/1467-6486.00390

Rothmann, S., \& Barkhuizen, N. (2008). Burnout of academic staff in South African higher education institutions. South African Journal of Higher Education, 22(2), 439-456. http://dx.doi.org/10.4314/sajhe.v22i2.25796

Sağlam, A.Ç. (2011). Relationship of socio-demographic characteristics of academicians with their burnout levels. Mustafa Kemal University Journal of Graduate School of Social Sciences, 8(15), 407-420.

Schwarzer, R., Schmitz, G.S., \& Tang, C. (2000). Teacher burnout in Hong Kong and Germany: a cross cultural validation of Maslach Burnout Inventory. Anxiety, Stress, and Coping. 13, 309-326. http://dx.doi.org/10.1080/10615800008549268

Şehitoğlu, Y. (2010). Connections between organizational silence organizational citizenship behavior and perceptive employee performance. Unpublished doctoral dissertation. Gebze High Technology Institute Graduate School of Social Sciences. Kocaeli, Turkey.

Şimşek, E., \& Aktaş, H. (2014). The interactions of organizational silence with personality and life satisfaction: A research on public sector. Anadolu University Journal of Social Sciences, 14(2), 121-136.

Tahmasebi, F., Sobhanipour, S.M., \& Aghaziarati, M. (2013). Burnout; explaining the role of organizational silence and its influence (Case study: Selected executive organizations of Qom province). Journal of Basic and Applied Scientific Research, 3(8), 272-282.

Toker, B. (2011). Burnout among university academicians: an empirical study on the universities of Turkey. Doğuş University Journal, 12(1), 114-127.

Tümkaya, S. (2000). Improving the scale of academic burnout. Hacettepe University Journal of Education Faculty, $19,128-133$.

Tülübaş, T. (2011). Öğretim elemanlarının sessiz kaldikları durumlar ve sessiz kalma nedenleri [Silence of faculty members: issues and causes of silence]. Unpublished master's thesis, Kocaeli University Graduate School of Social Sciences, Kocaeli. 
Tülübaş, T., \& Celep, C. (2014). Öğretim elemanlarının sessiz kalma nedenleri [Causes of Faculty Members' Silence]. Hacettepe University Journal of Education, 29(1), 280-297.

Ülker, F., \& Kanten, P. (2009). Örgütlerde sessizlik iklimi, işgören sessizliği ve örgütsel bağlllık ilişkisine yönelik bir araştırma [A Research on silence climate, employee silence, and organizational commitment relationship]. Journal of Aksaray University Faculty of Economics and Administrative Sciences, 1(2), 111-126.

Van Dyne, L., Ang, S., \& Botero, I.C. (2003). Conceptualizing employee silence and employee voice as multidimensional constructs. Journal of Management Studies, 40(6), 1359-1392. http://dx.doi.org/10.1111/1467-6486.00384

Watts, J., \& Robertson, N. (2011). Burnout in university teaching staff: a systematic literature review. Educational Research, 53(1), 33-50. http://dx.doi.org/10.1080/00131881.2011.552235

Yaman, E., \& Ruçlar, K. (2014). Örgüt kültürünün yordayıcısı olarak üniversitelerde örgütsel sessizlik [Organizational silence in universities as the predictor of organizational culture]. Journal of Higher Education \& Science, 4(1), 36-50. doi: 10.5961/jhes.2014.087.

Zamini, S., Zamini, S., \& Barzegary, L. (2011). The relationship between organizational culture and job burnout among the professors and employees in the University of Tabriz. Procedia-Social and Behavioral Sciences, 30, 1964-1968. http://dx.doi.org/10.1016/j.sbspro.2011.10.381 